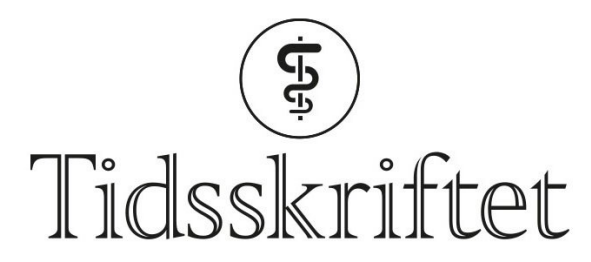

DEN NORSKE LEGEFORENING

\title{
Anti-IL-23-antistoffer mot prostatakreft?
}

FRA ANDRE TIDSSKRIFTER

HAAKON B. BENESTAD

Universitetet i Oslo

Interleukin (IL)-23 fra benmargsderiverte celler som infiltrerer kreftsvulsten, stimulerer vekst av kreftceller. Dette kan bli et angrepspunkt for immunterapi mot kastreringsresistent prostatakreft.

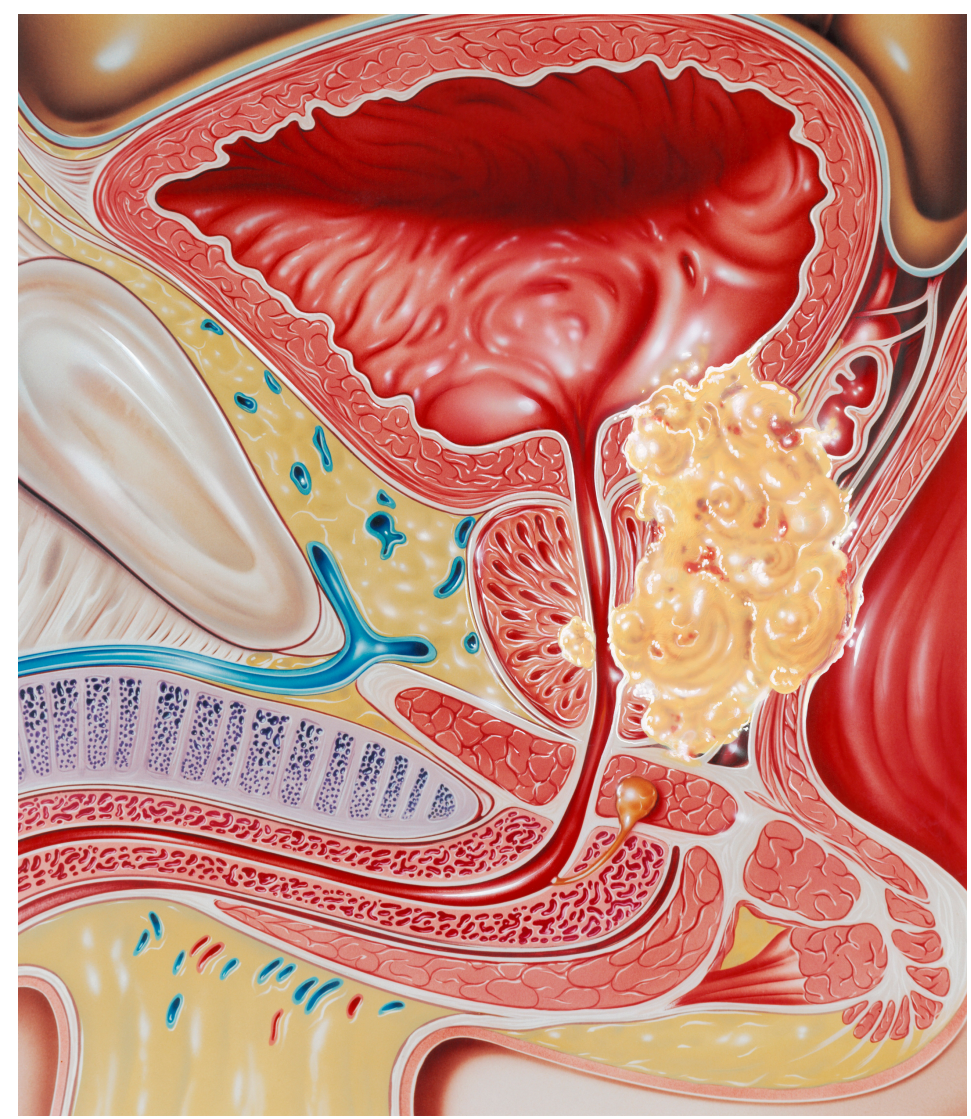

Prostatakreft. Fremstilling av en forstørret prostatakjertel som har invadert blcereveggen (over) og rektalveggen (til høyre). Illustrasjonsfoto: Science Photo Library / NTB scanpix

Prostatakreft behandles ofte med kjemisk kastrering. Men nesten alltid er vekststansen midlertidig, og kreften blir før eller senere kastreringsresistent. Benmargsderiverte suppressorceller finnes i mange krefttyper og stimulerer kreftvekst. Man har lenge trodd at kastreringsresistens opptrer autonomt i prostatakreft, men en ny studie tyder på at de 
benmargsderiverte suppressorcellene kan spille en rolle (1).

I en in vitro-modell med museceller fikk slike suppressorceller prostatakreftceller til å fortsette å vokse, selv uten tilsetting av androgener. Lignende funn ble gjort med menneskeceller. Farmakologisk reduksjon av antallet suppressorceller i musekreften utsatte utvikling av kastreringsresistens. I et klinisk materiale var det flere suppressorceller i kastrasjonsresistente svulster enn i kontrollsvulstene, og de produserte interleukin-23.

I musemodellen ble den intracellulære signalveien i kreftcellene påvist - fra det proinflammatoriske cytokinet IL-23 til syntese av økt antall androgenreseptorer og økt aktivering av gener som normalt stimuleres fra androgenreseptoren. Fors $ø \mathrm{k}$ med genetisk inaktivering av genene for IL-23 i benmargsceller og IL-23-reseptor i kreftceller bekreftet disse funnene. Kanskje er tiden inne til å forsøke antistoffer som blokkerer IL-23 mot kastrasjonsresistent prostatakreft?

- Disse resultatene er svært spennende, sier Johanna Olweus, som er professor ved Universitetet i Oslo og leder Seksjon for kreftimmunologi ved Institutt for kreftforskning ved Radiumhospitalet. - Forskerne har identifisert en viktig mekanisme for utvikling av kastrasjonsresistent prostatakreft. Ettersom antistoffer mot IL-23-p19-subenheten ser ut til å tolereres godt i kliniske studier, blant annet ved psoriasis, ligger forholdene godt til rette for utprøvning ved kastrasjonsresistent prostatakreft, mener hun.

- Kombinasjonen med en androgenreseptorinhibitor kan potensielt være lovende for en gruppe pasienter som man i dag ikke har mye å tilby. Dette vil i så fall bli nok et eksempel på at immunterapi med antistoffer kan gi synergi i kombinasjon med standard kreftbehandling, mener Olweus.

LITTERATUR:

1. Calcinotto A, Spataro C, Zagato E et al. IL-23 secreted by myeloid cells drives castration-resistant prostate cancer. Nature 2018; 559:363-9. [PubMed][CrossRef]

Publisert: 18. januar 2019. Tidsskr Nor Legeforen. DOI: 10.4045/tidsskr.18.0873

(C) Tidsskrift for Den norske legeforening 2020. Lastet ned fra tidsskriftet.no 